\title{
The Impact of Education on the Youth Labour Market in Serbia
}

\author{
Dejana Pavlović ${ }^{1, a^{*}}$, Ivana Domazet ${ }^{1, b}$ and Milena Lazić ${ }^{2, c}$ \\ ${ }^{1}$ Business Economics, Institute of Economic Sciences, Belgrade, Serbia \\ ${ }^{2}$ Economics and Finance, Belgrade Banking Academy, Belgrade, Serbia \\ adejana.pavlovic@ien.bg.ac.rs, bivana.domazet@ien.bg.ac.rs, 'milena.lazic@bba.edu.rs
}

\section{Keywords: Youth, Unemployment, Decision tree, Education.}

\begin{abstract}
The high rate of youth unemployment is an issue that is largely present in developing countries, such as Serbia. The results of the research will provide a major contribution whether education has an impact on the labour market among young people in Serbia. Decision tree was performed to identify impact constructs. In order to define public policies, an insight is provided into the characteristics of young people that largely contribute to the probability of being employed. The results showed that education has an impact on youth unemployment. Results of the research will be useful for decision makers in the implementation of a strategic model of the labour market. Theoretical and practical implications are discussed in the paper.
\end{abstract}

Subject Classification Numbers: J06, J08, J18.

\section{Introduction}

Following the onset of the global economic crisis, economic trends have led to a rising youth unemployment rate and reduced chances of young people finding jobs. In the last ten years, in developing countries, such as Serbia, about $40 \%$ of the young population (people aged from 15 to 24 ) is unemployed [1]. The main question that has become popular among researchers and decision makers is to identify how to reduce the high youth unemployment rate in Serbia [2-4].

The paper considered a group of social and economic indicators, such as education, regional differences and demographic indicators. The data used in the paper are obtained from the Labour Force Survey database of the Republic of Serbia [5], which for the purposes of this research was obtained from the Statistical Office of the Republic of Serbia.

The reasons for this research are multiple. We focused on developing countries such as Serbia because the problem of youth unemployment has become one of the most pressing issues. The latest statistics show that there is a large number of unemployed young people in Serbia [6], which further affects the increase in the informal employment rate [5]. Since 2008, more precisely following the onset of the financial crisis, the labour market for young people in Serbia has significantly shifted; so, the youth unemployment rate in the period from 2008 to 2012 rose from $35.2 \%$ to $51.1 \%$. A slight decline in the youth unemployment rate was recorded in the period from 2012 to 2015, when it down from $51.1 \%$ to $43.2 \%$. According to the latest date from 2016 , youth unemployment rate is $34.9 \%$. However, the youth unemployment rate is still above the average youth unemployment rate in the European Union, which is about 20\% [1].

On the other hand, not many studies have investigated the labour market of the Western Balkan countries. Numanović, Petreski and Tumanouska [7] analysed the key aspects of active labour market policies and their implementation in three Balkan countries - Albania, Bosnia and Herzegovina and Macedonia. They concluded that the level of public expenditure on active labour market policies is low in Albania, Bosnia and Herzegovina and Macedonia, and should be brought closer to the EU average ( $0.5 \%$ of GDP). Investment in research on reducing unemployment among young people is certainly of great importance for the Western Balkans. 
We focused on education because numerous authors became to conclusion that education has influence on the youth labour market. Arandarenko and Bartlett [8] found that the development of education and the improvement of labour force skills are a key factor that will underpin future economic recovery and growth of the Western Balkan economies. According to a group of authors [4], one of the solutions to reducing youth unemployment and helping young people to prepare for their future is to develop entrepreneurship skills among the youth.

For some time now, authors have considered that regional disparities [9-10] and education level have a significant impact on the youth unemployment rate [11]. The problem of regional differences in the labour market is also present in Serbia. By analysing the impact of regional differences in the labour market of the Republic of Serbia, Aradarenko [12] concluded that the causes of regional differences in the rates of the labour market might be the lack of jobs, lower wages, reduced inflow of investments, poor infrastructure and low skilled labour force in rural areas and small towns. Lack of jobs in underdeveloped regions leads to the development of the grey economy. According to the latest data from 2015, the unemployment rate (of the population aged 15 to 64 ) was $20.8 \%$ for the region of East and South Serbia, while in the Belgrade region it was about $18 \%$ [1]. The report of the Statistical Office of the Republic of Serbia (2016) showed that the largest number of employees receives a salary in the Belgrade region, while the lowest percentage of employees is in the region of Sumadija and Western Serbia. However, under such circumstances, the number of those employed in the grey economy is higher in Sumadija and Western Serbia than in Belgrade by as much as $16.2 \%$ [13].

The aim of the paper is to analyse, on the basis of the results of decision tree, to what extent education in Serbia influences the labour market for young people. In addition to insight into the statistical significance of education, the paper also presents an insight into the characteristics of young people that largely contribute to the probability of being employed, which will be useful for decision makers implementing labour policies.

\section{Theory}

Previous scientific research studies revealed that many political, economic and social factors can affect the high unemployment rate among young people. Zubović, Zdravković and Pavlović [14] analysed the impact of three groups of factors (unemployment related factors, population related factors and labour market regulation related factors) on the unemployment rate among young people in $41 \mathrm{EU}$ countries in the period from 2003 to 2014. The results showed that the tax rate on low earnings has the greatest impact on the level of unemployment among young people. According to research conducted by Gorry [15], professional experience and the amount of the minimum wage had a great impact on the unemployment rate among young people in France. He developed a model, which is based on the model by Mortensen and Pissarides [16], focusing on the impact of economic factors on the rate of unemployment among young people. Some studies have examined the impact of the financial crisis on unemployment, especially unemployment among young people $[10,17]$, while some authors think that study of the problem of the high unemployment rate among young people was current even before the crisis [18-19].

Moreover, a group of authors [20] addressed the impact of socio-economic factors on the unemployment rate by region in Russia ( 85 regions in Russia). They observed the impact that macroeconomic, institutional, structural, demographic and social variables produce on the rate of and interregional differences in rural unemployment. Based on the application of an econometric model, the results showed that a greater proportion of young people and a low level of education of young people in rural areas lead to increased unemployment.

In the Republic of Serbia, the reasons for high rates of inactivity and unemployment rates among young people are a low level of education of young people as an additional factor to late 
entry to the labour market $[3,21]$. A high unemployment rate in the local social environment has an impact on the academic performance of children [22]. When it comes to the regional development of Serbia, about $23 \%$ of people have secondary or higher education in urban municipalities; while in rural areas only around $6 \%$ of people have completed higher education. According to the 2011 census, more than $51 \%$ of young people have primary education or less than primary education in rural and poorly developed municipalities [5]. Higher education is connected with the labour market, and the most recent research investigated the influence of the demand for higher education on the labour market outcomes of skilled university graduates and unskilled-secondary school graduates [23-25].

A number of researchers have found that high unemployment rates are more prevalent in regions with low investments in human capital [20]. From the twentieth century onwards, human capital, which includes knowledge, skills and abilities of an individual, became a key determinant of economic growth and development. Investment in human capital, more precisely in education, would contribute to labour market stability. The results of empirical studies have helped decisionmakers in achieving competitive advantage through the use of its resources [26-27].

\section{Materials and Methods}

We used two methodological steps:

1. Construction and quantification of dependent and independent variables using the available dataset from the Labour Force Survey (Standard ILO methodology)

2. Estimation of decision tree model.

As a dependent variable, we consider a bivariate indicator describing two states of youth employment: it takes value 1 if a youngster is employed, 0 otherwise. The independent variables are grouped to the key explanatory and control variables. The key explanatory variables include:

- Development of the region (in which an individual is settled), being an indicator of regional disparities. It ranks four NUTS 2 administrative regions in Serbia with respect to relative income, measured by difference in GDP per capita of the given region and Republic average $^{1}$ : 1 - City of Belgrade; 2 - Vojvodina (Northern Serbia); 3 - Sumadija and Western Serbia; 4 - Southern and Eastern Serbia. Relative income of regions 1 and 2 is positive (i.e. regional GDP is higher than the Republic average), while in the case of regions 3 and 4 it is negative.

- Settlement type, being an indicator of local disparities. It ranks settlements to the level of urbanization: 1 if urban; 2 if rural.

The remaining variables are added to the model to control other characteristics that arguably may influence whether a youngster is or is not employed. They are grouped into demographic (gender, marriage, age), educational (the highest level achieved in formal education, informal education) and socioeconomic (size and finances of the household) variables. The specification of the control variables is given in the following Table 1 :

\footnotetext{
${ }^{1}$ According to http://www.privreda.gov.rs/wp-content/uploads/2017/03/Uredba-O-Utvrdjivanju-Jedinstvene-Liste-Razvijenosti-Regiona-I-JLS-Za2014..pdf
} 
Table 1. Definition of control variables

\begin{tabular}{|c|c|c|}
\hline Variable name & Type & Scale \\
\hline Gender & Nominal & 1 if male, 2 if female \\
\hline Age & Ratio & $15-29$ \\
\hline marriage* & Nominal & 1 if not married, 2 if married \\
\hline formal education & Ordinal & 1 if no education -13 if $\mathrm{PhD}$ \\
\hline informal education & Nominal & 1 if yes, 2 if not \\
\hline household size & Ratio & $1-13$ \\
\hline household's finances & Ordinal & 1 if good -4 if bad \\
\hline
\end{tabular}

Source: Authors' calculations

The dataset used in the analysis is taken from the Labour Force Survey in 2016 (data for 2017 not available yet), conducted by the Statistical Office of the Republic of Serbia. The methodology of the survey is fully in accordance with that applied in EU countries. The original dataset includes a large number of observed characteristics for a sample of 95,026 individuals settled on the territory of Serbia (without Kosovo). We limited our analysis to a subsample of individuals aged from 15-29, along with the international standard of defining the youth cohort, which includes 15,753 observations. Statistical analysis was performed using Rapid Miner Software.

The total number of active young people is computed as the sum of employed and NEET (not in employment, education or training) individuals, counting 7,070 observations and making up a $44.9 \%$ share in the total youth subsample. The observed rate of youth unemployment (at the Republic level) is $37.67 \%$.

\section{Results}

The dependent variable of decision tree is employment status which has two classes, employed or unemployed. The root of this tree contains all 15753 observations in this dataset. Classification accuracy is $77.35 \%$ (Table 2). The most influential attribute to determine how to classify an employed or unemployed is the participants' age attribute, which represents branching at the first and second levels. The majority of the people $(8314-52.78 \%)$ in the research that had a less than 22.5 years also had an unemployment status.

Table 2. Confusion Matrix for decision tree algorithm

\begin{tabular}{|c|c|c|c|}
\hline & true 2 & true 1 & class precision \\
\hline pred. 2 & 10174 & 2396 & $80.94 \%$ \\
\hline pred. 1 & 1172 & 2011 & $63.18 \%$ \\
\hline class recall & $89.67 \%$ & $45.63 \%$ & \\
\hline
\end{tabular}

Source: Authors' calculations 
Age $\leq 22.500: 2\{2=7402,1=912\}$

Age $>22.500$

\section{Age $\leq \mathbf{2 5 . 5 0 0}$}

Education $=$ No formal education: $2\{2=18,1=2\}$

Education $=$ Elementary school $1-4$ grade: $1\{2=7,1=7\}$

Education $=$ Elementary school up to 7 th grade: $2\{2=22,1=9\}$

Education $=$ Elementary school up to 8 th grade: $2\{2=157,1=81\}$

Education $=$ Secondary vocational school up to 2 nd grade: $1\{2=12,1=13\}$

Education $=$ Secondary vocational school up to 3 rd grade:

| | | Work experience $\leq$ 0.250: $2\{2=67,1=0\}$

| | | Work experience $>0.250: 1\{2=185,1=323\}$

| Education $=$ Secondary vocational school up to 4 th grade: $2\{2=870,1=456\}$

| Education $=$ Gymnasium: $2\{2=302,1=47\}$

| $\mid$ Education $=$ Specialization after secondary school, college for highly skilled workers: 1 $\{2=2,1=6\}$

Education $=$ Higher school, first degree of the faculty (according to the old program)

| | | Marital status $=$ Single: $2\{2=51,1=50\}$

| | | Marital status = Married: $1\{2=4,1=5\}$

| $\mid$ Education $=$ Faculty, academy, basic academic studies, high vocational college: 2 $\{2=289,1=152\}$

$\mid \quad$ Education $=$ Master and integrated studies (medicine, pharmacy, dentistry): $2\{2=41$, $1=27\}$

\section{| Age $>25.500$}

| | Household's finances $=$ Bad

| | | Region = Belgrade: $2\{2=185,1=148\}$

| | | Region = Vojvodina: $2\{2=255,1=159\}$

| | | Region = Sumadija and Western Serbia: $1\{2=265,1=280\}$

| | | Region = South and East Serbia: $2\{2=300,1=166\}$

| | Household's finances $=$ Mostly good: $1\{2=382,1=811\}$

| | Household's finances $=$ Mostly bad: $1\{2=486,1=683\}$

| | Household's finances $=$ Very good

| | | Region = Belgrade: $1\{2=12,1=15\}$

| | | Region = Vojvodina: $1\{2=10,1=33\}$

| | | Region = Sumadija and Western Serbia: $1\{2=8,1=15\}$

| | | Region = South and East Serbia: $2\{2=14,1=7\}$

*1- employed; 2 - unemployed;

Figure 1. Decision tree for regional and local disparities on youth unemployment 
The key factors determining employment status for those from 22.5 to 25 years are the educational level, marital status and work experience. Respondents with a lower education level (No formal education, Elementary school, Secondary vocational school up to 2nd grade) generally often face hurdles in job finding, which is the result of their previous education. On the other hand, respondents who completed Secondary vocational school up to 3rd grade and whose work experience exceeds 0.25 years mostly belong to the category of employees. They don't have the option to continue their studies at the faculties, and therefore have a minimum of 9 years of experience in job search and money-related activities with 22.5 years. Respondents who opt for higher levels of education (college and master) are mostly financed by parents who affect their status as unemployed, while if they are married, they will tend to get more engaged (Fig.1.).

The key factors determining employment status for those over 25 years are the household's finances and region. If the respondents characterized Household's finances as a bad, they are mostly unemployed, except for Sumadija and Western Serbia. Furthermore, respondents who believe that they are in a very good financial situation are mostly employed, except in the South and East Serbia region. Respondents who think that household's finances are mostly bad or good are usually employed (Fig.1).

\section{Conclusions}

The adoption of appropriate solutions is a top priority for decision makers. The problem of youth employment was present in the last century in developed European countries, too. As a solution to the problem of 'youth unemployment', EU member states have implemented active labour market policies, similar to those Sweden implemented back in 1984, Norway in 1993 and Denmark and Finland in 1996 [28]. The primary goal of these policies was to reduce the period of unemployment and inactivity of young people, and therefore, the needs of young people were identified in order to offer those suitable jobs or training during their education [29]. On the other hand, informal employment problem of low pay and poor or hazardous working conditions are specifically related with IT industry [30-31].

Previous results of the researches displayed that a large number of social and economic indicators had influence on the position of young people at the labour market. Throughout the research we included several important indicators such as age, gender, marriage, education, household's size and household's finance, leading us to the findings that for the age box from 22,5 to 25 the most influential employment factors are education level, marital status and work experience. This means that young people with excellent educational background, working experience and marital status are capable of finding their job opportunities more easily. Furthermore, in the case of young people over 25, we came to important indicators such as household's finance and regions which highly contribute to better job offers depending on higher family status, better family connections as well as more developed region in which they live.

It is important to emphasize that in this research we included a limited number of previously mentioned indicators although former researches and examples of other exacting strategies in the region implied other equally important indicators such as wages, regional differences and large number of macroeconomic factors that highly influence employment opportunities of young people. This results in further need to include some of these indicators in our future researches. Moreover, the research has a certain limitation that refers to the fact that we covered only one country and according to that the findings of our research it cannot be base for general conclusion unless we introduce one more country in order to provide a comparative analysis.

Our findings and recommendations can be used for the creation of regional labour market strategies and projects for investment in regional development. Also, it will be useful for future scientific studies on the youth labour market, especially in developing countries. 


\section{Conflict of Interest}

The authors declare that there is no conflict of interest.

\section{References}

[1] Statistical office of the Republic of Serbia, Labour Force Survey (2016) [Survey]. Available: http://www.stat.org.rs.

[2] M. Arandarenko, Tržište rada u Srbiji, Faculty of Economics, University of Belgrade, Belgrade, Serbia, 2011.

[3] D. Pavlović, J. Zubović, A. Zdravković, Youth expectations in job search in Serbia, Industry. 44(4) (2016) 4-17.

[4] I. Todorović et al., Strategic Management in Development of Youth and Women Entrepreneurship - Case of Serbia, Organizacija. 49(4) (2016) 197-207.

[5] Statistical office of the Republic of Serbia, Labour Force Survey (2015) [Survey]. Available: http://www.stat.org.rs.

[6] International Labour Organization, Statistics and databases (2016) [Databases]. Available: http://www.ilo.org/global/statistics-and-databases/lang--en/index.htm.

[7] A. Numanović et al., Weak labour markets, weak policy responses: active labour market policies in Albania, Bosnia and Herzegovina and Macedonia, Analitika, Center for Social Researches, Sarajevo, Bosnia and Herzegovina, 2016.

[8] M. Arandareno, W. Bartlett (Eds.), Labour market and skills in the Western Balkans, FREN, Belgrade, Serbia, 2012.

[9] O. Demidova, E. Marelli, M. Signorelli, Youth labour market performances in the Russian and Italian regions, Economic Systems. 39 (2015) 43-58.

[10] E. Kelly, S. McGuinness, Impact of the Great Recession on unemployed and NEET individuals' labour market transitions in Ireland, Economic Systems. 35 (2015) 59-71.

[11] L. Refrigeri, G. Aleandri, Educational policies and youth unemployment, Social and Behavioral Sciences. 93 (2013) 1263-1268.

[12] M. Arandarenko, Mapa tržišta rada Srbije, Ocena regionalnih razlika i potencijala, Centre for High Education Belgrade, Belgrade, Serbia, 2006.

[13] Statistical Office of Republic of Serbia, Municipalities and regions of the Republic of Serbia (2016). Available: http://www.stat.gov.rs/en-us/publikacije/publication/?p=9844

[14] J. Zubović, A. Zdravković, D. Pavlović, Effects of regulation on youth unemployment: evidence from European countries, Industrija. 43(2) (2015) 129-144.

[15] A. Gorry, Minimum wages and youth unemployment, European Economics Review. 64 (2013) 57-75.

[16] D. Mortensen, C. Pissarides, 1994 Job Creation and Job Destruction in the Theory of Unemployment, The Review of Economic Studies. 61 (1994) 397-415.

[17] I. Domazet, D. Marjanović, Foreign direct investment in the function of economic development: Example of selected countries in the Western Balkan, International Letters of Social and Humanistic Sciences. 79 (2017) 1-15.

[18] V. Vasile, Crisis impact on employment and mobility model of the Romanian university graduates, Procedia Economics and Finance. 3 (2012) 315-324. 
[19] S. Marginean, Youth unemployment in Romania: post-crisis challenges, Economics and Finance. 16 (2014) 613-620.

[20] T.V. Blinova, G.S. Bylina, V.A. Rusanovsky, Factors and determinants of interregional unemployment rate differences in rural Russia, Agricultural Sciences. 7 (2016) 630-641.

[21] I. Domazet, Improving competitiveness and economic development through FDI, in: Developmental State and Millennium Development Goals, Brisbane, Australia, 2018, pp. 93107.

[22] S. Cankar Setnikar et al., The impact of social and economic factors on the academic performance on youth in Slovenia, Journal of Local Self-Government. 13(3) (2015) 661-668.

[23] A. Chevalier, J. Lindley, Over education and the skills of UK graduates, Journal of Royal Statistics Society: Series A. (2) (2009) 307-337.

[24] G. Bosio, M. Leonardi, The impact of Bologna process on graduate labor market, Demand and supply, Giornale Degli Economisti. 69(3) (2010) 29-66.

[25] P. Carneiro, S. Lee, Trends in quality-adjusted skill premia in the United States, 1960-2000, American Economic Review. 106(1) (2011) 2309-2349.

[26] P. Boselie, C. Brewster, J. Paauwe, In search of balance - managing the dualities of HRM: An overview of the issues, Personnel Review. 38(5) (2009) 461-471.

[27] I. Domazet, D. Marjanović, FDI as a factor of improving the competitiveness of developing countries: FDI and competitiveness, in: Foreign Direct Investments (FDIs) and Opportunities for Developing Economies in the World Market, Hershey, 2018, pp. 82-104.

[28] M. Mascherini, Youth guarantee: Experiences from Finland and Sweden, European Foundation for the Improvement of Living and Working Conditions, Dublin, 2012.

[29] D. Pavlovic, The impact of human resource management of the work design concept in Serbia, Economic Analysis. 42(1) (2017) 86-92.

[30] T. Barnes, The IT industry, employment and informality in India: Challenging the conventional narrative, The Economic and Labour Relations Review. 26(1) (2015) 82-99.

[31] I. Domazet, I. Stošić, Strengthening the competitiveness of Serbian economy and the corporate market restructuring, Economyc Analysis. 46(3-4) (2013) 108-124. 